\title{
RADIOGRAFÍA DE LA SOCIEDAD POSMODERNA
}

Montero Guerrero, Rubén Universidad Peruana Unión rubenm32@yahoo.com

Fecha de recepción: Abril 2013 Fecha de aceptación y versión final: Junio 2013

Vivir en una sociedad posmoderna, caracterizada por un discurso antirreligioso y por su relativismo moral, constituye, en si mismo, un gran desafio para los cristianos, especialmente para el segmento más joven. Este artículo ofrece una descripción de algunas de las características de nuestra sociedad que nos permitirán conocerla mejor y comprender el enorme desafí que ella presenta para quienes enarbolan los principios de la fe cristiana.

Palabras clave: Sociedad, posmodernidad, relativismo, cristianismo. 
Summary: Living in a postmodern society, characterized by an anti-religious environment and its moral relativism, formulates a great challenge for Christians, especially for the younger segment. This article provides an overview of some of the features of our society that will allow us to know her better and understand the enormous challenge it presents for those who brandish the principles of the Christian faith.

Keywords: Society, postmodernism, relativism, christianity. 
"El único remedio para los pecados y dolores de los hombres es Cristo. Solamente el evangelio de su gracia puede curar los males que azotan a la sociedad. La injusticia del rico hacia el pobre, el odio del pobre hacia el rico, tienen igualmente su raíz en el egoísmo, el cual puede extirparse unicamente por la sumisión a Cristo. Solamente Él da un nuevo corazón de amor en lugar del corazón egoísta de pecado. Prediquen los siervos de Cristo el evangelio con el Espiritu enviado desde el cielo, y trabajen como Él lo hizo por el beneficio de los hombres. Entonces se manifestarán, en la bendición y en el ennoblecimiento de la humanidad, resultados que serían totalmente imposible alcanzar por el poder humano".

Elena de White, 1900

\section{Introducción}

Mario Vargas Llosa, empieza su descripción de lo que él llama la Civilización del Espectáculo, ${ }^{1}$

1 Mario Vargas Llosa, "La Civiliza- contando un hecho ocurrido el viernes 19 de setiembre de 2008, día en que se desplomó la bolsa de valores de Nueva York, y cientos de fotógrafos de los más importantes medios de comunicación estaban agolpados en los exteriores de uno de los imponentes rascacielos. Todos querían llevar a sus redacciones la primicia del primer bróker que se lanzase desde las alturas, a consecuencia de ese terrible huracán financiero que vaporizó miles de millones de dólares.

Es espeluznante la visión de un grupo de personas ávidas por registrar gráficamente el muy probable suicidio de algún bróker caído en desgracia, sin embargo, el cuadro se hace más sorprendente cuando pensamos que muchos podrían sentirse decepcionados por el hecho que no hubo ningún suicida que se arrojase del rascacielo.

La imagen de la desgracia de un suicida hubiese signifi-

ción del Espectáculo", Revista Letras Libres, (2009). 
cado un gran éxito profesional para los fotógrafos, con el consiguiente engrosamiento de sus cuentas bancarias.

\section{La violencia y los medios de comunicación}

Las imágenes de la violencia y del aparente triunfo inexorable de la irracionalidad están en todas partes del mundo: desde los movimientos terroristas hasta los movimientos separatistas en algunas naciones europeas, desde las guerras contra el narcotráfico y sus secuelas en los países andinos hasta las infernales guerras tribales en algunos países africanos, desde los ancestrales odios entre judíos y árabes hasta las amenazas de extremistas islámicos que penden como una espada de Damocles sobre la cabeza de la civilización occidental.

Asimismo, podemos ver a los omnipresentes medios de comunicación tratando de buscar el ángulo más sangriento de la tragedia humana, y convirtiéndose en una festiva comparsa consagrada a adular el insaciable clamor de las masas por más derramamiento de sangre. En su carrera sin tregua por capturar al mayor número de consumidores, los noticieros del mundo parecen deleitarse en colocar en sus primeras planas lo peor de la sociedad humana, haciendo que esta parezca mucho peor y miserable. Para completar este dramático escenario, parece haberse instalado, en la conciencia universal de la humanidad, la certeza indubitable que no hay manera de salir de esta situación. Es evidente que se vive en un mundo en crisis y que se es parte de una sociedad enferma.

\section{Modernidad y posmodernidad}

Si repasamos la historia veremos cómo, el siglo XX, se inició con un optimismo generalizado en la capacidad del hombre por construir una sociedad mejor. Se creía que la razón sería el instrumento que realizaría la portentosa hazaña de construir un mundo donde los seres huma- 
nos podrían alcanzar la felicidad y vivir en perpetua armonía. Esa sociedad, que tenía una confianza ciega en el poder de la razón humana para solucionar los mayores problemas de la humanidad, constituye el apogeo de la modernidad. ${ }^{2}$

La modernidad fue una época de grandes metas, del ideal del progreso conjunto de la humanidad bajo la guía de la razón, la época de la lucha de las ideolo-

2 Sobre lo que es la modernidad y su confianza en el progreso humano a través de la razón, es interesante el comentario de Vattimo: "Desde el punto de vista (que podemos considerar común a pesar de no pocas diferencias) de Nietzsche y de Heidegger, la modernidad se puede caracterizar, en efecto, como un fenómeno dominado por la idea de la historia del pensamiento, entendida como una progresiva "iluminación" que se desarrolla sobre la base de un proceso cada vez más pleno de apropiación y reapropiación de los "fundamentos", los cuales a menudo se conciben como los "orígenes", de suerte que las revoluciones, teóricas y prácticas, de la historia occidental se presentan y se legitiman, por lo común, como "recuperaciones", renacimientos, retornos". Gianni Vattimo, El fin de la modernidad: Nihilismo y hermenéutica en la cultura posmoderna (Barcelona, España: Editorial Gedisa SA, 1987), 10. gías, cada una mostrándose a sí misma como el único camino racional para alcanzar la plena felicidad y la ansiada armonía entre los seres humanos. Las ideologías, con una arquitectura lógica indestructible, convencían a millones de seres humanos que luchaban por sus banderas políticas, económicas y sociales en la convicción de transformar la sociedad hasta conquistar el paraíso que su ideología prometía.

Esas ideologías eran visiones de la realidad, explicaciones totalizadoras sobre la naturaleza del ser humano y el devenir de la historia universal. ${ }^{3}$ Entre estas

3 Podríamos decir que esas ideologías totalizadoras son las que Lyotard llama de metarrelatos. En su libro La Posmodernidad (explicada a los niños), él escribe: "Cuando la enfoqué, en 1979, en torno de la cuestión de los "grandes relatos", mi intención era simplificarla, pero me temo que fui más allá de lo necesario. Los "metarrelatos" a que se refiere La condición posmoderna son aquellos que han marcado la modernidad: emancipación progresiva de la razón y de la libertad, emancipación progresiva o catastrófica del trabajo (fuente de valor alienado en el capitalismo), enriquecimiento de toda la humanidad a través del progreso de la tecnociencia capi- 
ideologías podemos citar al marxismo, el iluminismo, el capitalismo y también al cristianismo. ${ }^{4}$

Fue en los albores del siglo XX que el ideal de la modernidad empezó a dar señales de agotamiento hasta, finalmente, ser desplazado por la visión escéptica de la posmodernidad. Conforme transcurría el siglo pasado, eran cada vez más evidentes las exiguas capacidades de la razón para construir el ideal de una sociedad de paz y armonía.

talista, e incluso, si se cuenta al cristianismo dentro de la modernidad (opuesto, por lo tanto, al clasicismo antiguo), salvación de las criaturas por medio de la conversión de las almas vía el relato crístico del amor mártir”. Jean Francois Lyotard, La posmodernidad (explicada a los niños) (Barcelona, España: Editorial Gedisa SA, 1996), 29-32.

4 Aun cuando se considere al cristianismo como una ideología con visión totalizadora en la modernidad, es llamativo constatar que el cristianismo se hallaba también como una sobria columna en el andamiaje intelectual de la edad media, frente a la cual se levantó el paradigma de la modernidad. Para el creyente, esta persistente vigencia en el tiempo es un argumento a favor de la superioridad del cristianismo sobre otras visiones integrales de la vida.
Dos grandes guerras mundiales fueron golpes devastadores contra la modernidad. El hombre había alcanzado a través de la razón las cumbres de la ciencia y la tecnología, pero también la humanidad se descubría a sí misma en los umbrales del infierno de un holocausto nuclear. La razón había llevado a la humanidad a conquistas extraordinarias en la ciencia, pero esas conquistas, lejos de llevarla al ideal de la sociedad perfecta, se volvían contra el propio hombre. Con todo su adelanto científico, el hombre no había avanzado un milímetro en la construcción de una sociedad que garantice la felicidad y la plenitud al ser humano. Un sentimiento de desilusión estremece el corazón de la humanidad.

Este sentimiento es una respuesta casi exclusivamente emocional a los ideales frustrados de la modernidad. Esa respuesta moldeó lo que se llegó a llamar la sociedad posmoderna. Habermas grafica muy bien ese sentimiento, declarando: "La posmo- 
dernidad se presenta claramente como antimodernidad". 5 Es la sociedad posmoderna, con sus grandezas y miserias, la sociedad en que vivimos. A continuación presentaremos algunos de los rasgos más notables de la posmodernidad.

\section{Un mundo sin ideales}

Uno de los rasgos distintivos de la modernidad era su confianza en la razón humana. Esa confianza en la razón tuvo su impacto en los ámbitos de la ciencia y el pensamiento social y político. En la modernidad, existía la disposición a creer que era posible alcanzar los ideales sociales y políticos que ofrecen las ideologías: la libertad, la igualdad, una sociedad sin clases sociales, el acceso universal al mercado, etc. En virtud de la consecución de esos ideales, se justificaban la militancia política y el compromiso con las causas sociales. La modernidad fue el tiempo de las

5 J. Habermas, J. Baudrillard, E. Said, F. Jameson y otros, La Posmodernidad. 7ma. Ed. por Hal Foster (Barcelona: Editorial Kairós SA, 2008), 19. grandes utopías sociales y de los actos de fe. No se está evaluando aquí la validez o la veracidad de estos ideales u utopías, lo que se hace simplemente es describir el sentimiento de la modernidad. La posmodernidad arrasa con las ideas totalizadoras e ideologías movilizadoras, dando paso a un mundo sin ideales por conquistar. Las conquistas se trasladan al campo individual. No se lucha más por la sociedad perfecta, ahora la lucha es por el éxito personal. Los grandes ideales movilizadores han dado paso a la feroz competencia en los diferentes ámbitos de la existencia.

\section{Un mundo de sentimen- talismos exacerbados}

En nuestra sociedad, el ideal racionalista basado en el principio cartesiano, "pienso luego existo", ha sido desplazado por uno que podríamos enunciar como "siento luego existo". La preponderancia de los medios visuales es abrumadora, y las multitudes son arrastradas hacia un universo virtual de imágenes 
que emocionan, aterrorizan, hacen reír y hacen llorar. Parece que solo aquello que toca las fibras de la emoción parece ser digno de ser seguido. La reflexión y la contrastación de ideas han sido relegadas al ostracismo mediático. Daniel Bell, describe esta realidad de esta manera:

...Los medios visuales, el cine y la televisión, imponen su ritmo al espectador y, al destacar las imágenes y no las palabras, no invitan a la conceptualización sino a la dramatización. En el énfasis que las noticias de la televisión ponen los desastres y las tragedias humanas, no instan a la purificación o a la comprensión, sino al sentimentalismo y la piedad, emociones que se agotan rápidamente, y crean un seudorritual de seudoparticipación en los sucesos. Y, como la modalidad es inevitablemente de superdramatización, las respuestas pronto se hacen altisonantes o aburridas... 6

6 Daniel Bell, Las contradicciones culturales del capitalismo (Azcapotzalco, México DF: Editorial Patria SA, 1989), 110.
Estas sucesiones de vivencias y de emociones superficiales producen una sociedad superficial. No importa tanto ser compasivo como parecer compasivo. Esta serie de apelaciones superficiales y emotivas destruyen cualquier compromiso real y altruista por el bienestar del prójimo y de la sociedad en general. Es lo que Lipovetsky ha llamado una moral sentimental mediática, veamos el párrafo completo, para entender mejor lo que él dice al respecto:

...El proceso de erosión de los deberes continua: mientras los medios apelan periódicamente a los corazones, desculpabilizan las conciencias y trabajan, tal vez subterráneamente, para apartar a los individuos de las obligaciones permanentes de ayuda y beneficencia. El altruismo del posdeber se complace en la distancia: nos hemos vuelto más sensibles a la miseria expuesta en la pequeña pantalla que a la inmediatamente tangible, hay más conmiseración hacia el semejante distante que hacia nues- 
tro prójimo cercano. La caridad de los medios no culpabiliza, no da lecciones de moral, conmueve mezclando el buen humor y los sollozos contenidos, las variedades y los testimonios intimos, las hazañas deportivas y los niños impedidos. No ya una moral de la obligación sino una moral sentimental mediática... ${ }^{7}$

\section{Un mundo con una ética relativista}

Entre los filósofos que más han influenciado en la sociedad posmoderna, podemos citar a Friedrich Nietzsche, aun cuando él mismo, por razones obvias, no estuvo en el centro del debate de lo moderno versus lo posmoderno. Nietzsche es uno de los más furibundos detractores de la doctrina platónica y del cristianismo, que concebían la existencia de un mundo ideal, apartado del mundo material e imperfecto, un mundo de ideas y valores absolutos. Según Nietzsche los

7 Gilles Lipovetsky, El crepúsculo del deber. La ética indolora de los nuevos tiempos democráticos (Barcelona, España: Editorial Anagrama SA, 1994), 138. valores como el bien y la verdad no son absolutos, eternos y universales, sino que son social e históricamente construidos y, por lo tanto, contingentes. Al comenzar su libro Asi hablaba Zaratustra, Nietzsche afirma: "Mas cuando Zaratustra estuvo solo, habló así a su corazón: ¡Será posible! ¡Este viejo santo en su bosque no ha oído todavía nada de que Dios ha muerto!"8

Esa proclamación de la "muerte de Dios", es, según Nietzsche, una buena noticia para el ser humano, porque significa que el hombre ya no tiene que depender de valores absolutos que otros crearon, ahora el hombre es libre de crear un nuevo sistema de valores. Él propone un sistema de valores que ya no esté basado en la moral judeo-cristiana, que considera una moral de esclavos. Lo que Nietzsche propone es una moralidad del fuerte, de la afirmación del valor de la vida, de la voluntad de poder.

8 Friedrich Nietzsche, Así habló Zaratustra (Valladolid, España: Editorial Maxtor, 2007), 8. 
Esa nueva moral sería propia del superhombre, que sería el pináculo de la evolución humana, alguien seguro, independiente y muy individualista. Alguien despojado de las ideas religiosas y plenamente centrado en el mundo real.

La sociedad posmoderna está impregnada de este tipo de pensamiento. No hay lugar para los valores absolutos, cada hombre construye su propio sistema de valores. Lo bueno y lo malo dependen de cada ser humano. En realidad este relativismo no es nuevo, es simplemente la reedición del viejo apotegma de Protágoras: "el hombre es la medida de todas las cosas". Esa negación de valores fundamentales tarde o temprano deriva en el caos social. El propio Nietzsche fue usado para justificar uno de los más sanguinarios genocidios de la historia de la humanidad, hay evidencias documentadas del uso que hicieron los nazis de las ideas de Nietzsche para sustentar su ideología pangermanista. ${ }^{9}$

9 Osvaldo Giacóia-Junior, conside-
Este relativismo también se ha extendido a las artes. En una conversación que sostuvieron Mario Vargas Llosa y Gilles Lipovetsky, a propósito de la publicación de La civilización del espectáculo, Vargas Llosa afirmó:

La libertad que las artes plásticas han adquirido consiste en que todo puede ser arte y nada lo es. Que todo arte puede ser bello o feo, pero no hay manera de saberlo; no tenemos el canon que antes existía y que nos permitía diferenciar lo excelente de lo regular y de lo execrable: hoy todo

rado uno de los autores brasileños, que mejor ha interpretado el pensamiento nitzscheano, sostiene que los nazis se apropiaron de la obra de Nietzsche con propósitos publicitarios, aprovechándose, sobre todo, de la relación cercana de la hermana de Friedrich Nietzsche con el partido nazi, para darle al nazismo cierta verosimilitud académica. Giacóia-Junior sostiene, sin embargo, que no hay una verdadera aproximación entre el pensamiento de Nietzsche y una ideología totalitaria como el nazismo. Entrevista en vídeo a Osvaldo Giacóia-Junior, Influência de Nietzsche no nazismo. Sin mayores informaciones. http://www.youtube.com/ watch?v=kzkW4CUFiB4 (Consultado: 19 de mayo, 2013). 
puede ser excelente o execrable. Al gusto del cliente. ${ }^{10}$

\section{Un mundo narcisista}

La leyenda griega de Narciso nos muestra el triste destino de un hombre que se enamora de sí mismo al contemplar su reflejo en el agua. Se ha dado en llamar narcisismo al egoísmo exacerbado de quien solo piensa en su satisfacción personal y que crea un mundo girando alrededor de sí mismo. La cultura posmoderna propicia un marcado hedonismo que acentúa el individualismo. La consigna del individuo es mantenerse joven y hermoso. Se sobrevalora el placer y la búsqueda de la perfección corporal, se transforma en una obsesión porque, supuestamente, multiplica exponencialmente las oportunidades de dar y recibir placer.

Las dietas, ejercicios y tratamientos médicos no buscan principalmente la salud -no pocas

10 Mario Vargas Llosa y Gilles Lipovetsky, ¿Alta cultura o cultura de masas? Letras libres, N. ${ }^{\circ} 130$ (España: julio 2012): 10-16. veces son precisamente en detrimento de esta- sino que el objetivo explícito es lucir un cuerpo atractivo y lo más joven posible. Al mismo tiempo, los patrones de belleza y perfección física, difundidos por los medios de comunicación, dejan a una gran parte de la población insatisfecha con su apariencia personal y eso, en una cultura que sobrevalora la imagen, se convierte, para muchos, especialmente los más jóvenes, en una hecatombe emocional.

Lamentablemente, esa búsqueda de la perfección exterior no tiene, ni por asomo, un correlato en la búsqueda por la perfección interior. Este tipo de individuo se encaja perfectamente en la descripción que Ortega y Gasset hizo del hombre masa:

Más que un hombre, es solo un caparazón de hombre constituido por meres idola fori; carece de un "dentro", de una intimidad suya, inexorable e inalienable, de un yo que no se pueda revocar. De aqui que esté siempre en disponibilidad para fingir ser 
cualquier cosa. Tiene solo apetitos, cree que tiene solo derechos y no cree que tiene obligaciones: es el hombre sin la nobleza que obliga -sine nobilitate, snob. ${ }^{11}$

El cine y la televisión, y también la publicidad, nos muestran repetidamente los principales valores de nuestro tiempo. Tristemente la seducción, el goce, el placer y el culto al cuerpo figuran en los primeros lugares, dejando de lado valores más trascendentes como el bien, la verdad, la honestidad, la justicia, etc.

\section{Un mundo pervertido}

Que el mundo actual es prolífico en mostrar la más amplia e indeseable gama de conductas pervertidas no es un secreto para nadie. Entendiendo la perversión como la práctica de conductas extrañas en el sexo, en cierto sentido las conductas pervertidas se han manifestado en la humanidad desde la salida

11 José Ortega y Gasset, La rebelión de las masas (Santiago, Chile: Editorial Andrés Bello, 1996), 27. del jardín del Edén. Lo que parece ser diferente en la sociedad actual, es el extendido discurso contemplativo respecto de esas perversiones. Lo que antes se practicaba en secreto, ahora se hace a plena luz del día y en los lugares públicos.

El homosexualismo, por ejemplo, ha pasado de ser reprobado socialmente a ser aceptado y hasta estimulado, ya que prácticamente no hay serie exitosa de televisión que no tengan algún personaje homosexual que aparece como comprensivo y sensato, frente a no pocos personajes heterosexuales que son presentados como díscolos y promiscuos. Varios países, incluyendo a Argentina y Uruguay en nuestro vecindario sudamericano, han implementado el matrimonio homosexual como parte de su legislación, y muchos, incluyendo el Perú, están colocando en el debate público la posibilidad de permitirlo, aun con el manifiesto desacuerdo de la mayoría de la población. 
Por otro lado, millones de páginas de internet proporcionan incalculables ganancias a sus dueños con el negocio de la pornografía y la exposición de las conductas más repulsivas como el bestialismo, el sadomasoquismo, etc. Además, en las grandes ciudades hay barrios enteros consagrados a la prostitución callejera y a la exposición descarnada de las más viles pasiones humanas, degradando hasta niveles inimaginables al hombre y a la mujer que fueron creados a imagen de

\section{Dios.}

\section{Un mundo sin pasado}

Juan de Salisbury escribió, recordando a su maestro: "Decía Bernardo de Chartres que somos como enanos en los hombros de gigantes. Podemos ver más, y más lejos que ellos, no por alguna distinción física nuestra, sino porque somos levantados por su gran altura" 12 De esta manera, Bernardo de

12 Juan de Salisbury, Metalogicon, (1159), III, 2.
Chartres describía la enorme deuda que se tiene con los hombres del pasado. José Ortega y Gasset decía que la principal diferencia entre el hombre y la bestia estaba en que el hombre tiene la capacidad de recordar, es decir que tiene una memoria más poderosa, que registra sus acciones, buenas o malas, en tanto que la bestia casi enfrentaba cada día como si fuese el primer día de su existencia, lo que le hacía imposible aprender de sus errores y consolidar sus aciertos. ${ }^{13}$

Al margen de la presuposición evolucionista que gobierna esta aseveración, no hay duda que la historia y sus protagonistas tienen una gran influencia sobre la civilización actual, sobre lo que somos, lo que vivimos y lo que creemos. No sería posible la propia civilización sin el esfuerzo fragmentado de innumerables generaciones que contribuyeron en la arquitectura de la cultura actual. Pues bien, esa convicción 
de ser herederos de una larga y penosa conquista cultural, que abarca siglos, está ausente en la mentalidad del hombre posmoderno.

El hombre del siglo XXI tiene a su disposición los mayores avances tecnológicos de la historia, disfruta de la sociedad más opulenta que el mundo ha conocido y no tiene la menor idea de lo mucho que esa conquista ha costado en términos generacionales. El ser humano actual solo parece interesado en el aquí y en el ahora. Sobre esta vacuidad intelectual del hombre posmoderno, otra vez debemos citar al filósofo español Ortega y Gasset:

El hombre vulgar, al encontrarse con ese mundo técnica y socialmente tan perfecto, cree que lo ha producido la naturaleza, y no piensa nunca en los esfuerzos geniales de individuos excelentes que supone su creación... Estas masas mimadas son lo bastante poco inteligentes para creer que esa organiza- ción material y social, puesta a su disposición como el aire, es de su mismo origen, ya que tampoco falla, al parecer, y es casi tan perfecta como la natural. ${ }^{14}$

La constatación del poco interés que los hombres posmodernos muestran por la urdimbre de eventos que posibilitaron sus actuales beneficios sociales, políticos y tecnológicos; nos lleva a comprender la actitud de niños engreídos que tienen con respecto a usufructuar todos los derechos posibles sin estar dispuestos a comprometerse en el cumplimiento de los más elementales deberes para consigo mismos, con su entorno medioambiental y también con las siguientes generaciones. Una vez más cito a Ortega:

Y esto es ser un pueblo de hombres: poder hoy seguir en su ayer sin dejar por eso de vivir para el futuro; poder existir en el verdadero presente, ya que el

14 Ibíd., 95. 
presente es solo la presencia del pasado y del porvenir, el lugar donde pretérito y futuro efectivamente existen. ${ }^{15}$

\section{Un mundo de tribus}

Uno los más celebrados poemas de César Vallejo es Masa, ${ }^{16}$ donde describe la gran fuerza que tendría la humanidad de estar unida en un objetivo común. Estos versos empiezan mostrando un combatiente muerto al final de la batalla y algunos pocos que le ruegan que no se muera.

Solo cuando todos los hombres de la tierra se unen en un grito común contra la muerte, este cadáver se emociona, se levanta y se echa a andar. Este poema, que exalta la solidaridad y la fraternidad de la humanidad, constituye un ejemplo de las grandes ideas movilizadoras de la modernidad: la utopía de una sociedad perfecta, sin

\section{Ibíd., 45.}

16 César Vallejo, España, aparta de mí este cáliz, Edición comentada por Juan Larrea (Madrid, España: Gráficas MarCar, 1937), 141. clases sociales enfrentadas, sin violencia ni conflictos.

La posmodernidad arrasó con ese ideal de sociedad perfecta y presentó, en su lugar, la realidad de una sociedad fragmentada, diversificada y enfrentada. Una sociedad dividida en tribus, cada una pugnando por defender sus intereses y luchando por exponer y, en algunos casos, imponer su estilo de vida. Este aspecto es todavía más evidente cuando observamos el fenómeno de las tribus urbanas. Cada vez más los jóvenes desean ser aceptados en la sociedad, aun cuando para eso se tornen en algo que no son realmente. Muchas veces motivados por el quebrantamiento de sus relaciones familiares y de amistad, los jóvenes adolescentes entran en una búsqueda incesante por atención y aprobación, y terminan cayendo en situaciones oscuras y peligrosas para su integridad personal.

En las grandes ciudades los principios básicos de estas tribus son: grupos cohesionados bajo algún tipo de liderazgo, con gustos musicales semejantes, 
indumentarias semejantes y hábitos parecidos. Son grupos de individuos que reivindican un estilo de vida propio, un modo de vestir, gustos musicales que los unifican y con sus propios ideales políticos y éticos. Estos grupos continúan creciendo $\mathrm{y}$ multiplicándose, lo que demuestra que cumplen un papel al proporcionar un cierto sentido de pertenencia a una gran parte de la juventud decepcionada de la sociedad tradicional. Punks, góticos, emos, hippies, satánicos, chavs; son algunos de los muchos grupos juveniles, que caracterizan el paisaje social de nuestras atribuladas ciudades posmodernas.

\section{Un mundo light}

Otra característica de nuestro tiempo es el poco esfuerzo que se requiere para realizar actividades que, en épocas anteriores, demandaban un considerable trabajo. En tiempos pasados, el simple hecho de beber agua era muchas veces una pequeña odisea: se requería dirigirse hacia el pozo, lanzar al- gún recipiente y luego beber el agua en condiciones de salubridad que hoy consideraríamos inaceptables.

El simple hecho de cocinar, bañarse, desplazarse a otro lugar, eran pequeñas hazañas que formaban parte de la vida cotidiana de nuestros ancestros. La situación hoy es muy diferente, estamos tan acostumbrados al confort de la vida moderna que no valoramos el hecho de beber agua directamente en nuestra casa, de tener una ducha caliente para bañarse, de usar una cocina a gas para cocinar en lugar de ir diariamente a cortar leña, de usar los autos para desplazarnos en pocos minutos lo que antes llevaría días, y podríamos seguir mencionando innumerables aspectos de nuestra vida que se han facilitado por el vertiginoso avance de la tecnología.

Pero estos beneficios que disfruta el hombre moderno han tenido un pernicioso efecto colateral: un generalizado desdén para desarrollar cierta 
capacidad de lucha en la conquista de valores morales y en la superación de desafíos intelectuales y artísticos. Asistimos al predominio de una generación light, que no está dispuesta al esfuerzo y le tiene horror al sacrificio. Y hay multitud de cosas deseables que demandan un formidable sacrificio personal. Por ejemplo, la construcción de relaciones saludables en el matrimonio demanda grandes dosis de perseverancia y compromiso, pero el hombre posmoderno prefiere no esforzarse en esa dirección, entonces es superficial en la construcción y el cuidado de sus vínculos personales y familiares.

También demanda considerable esfuerzo el cultivo del intelecto y el refinamiento del disfrute estético, y el hombre promedio de la sociedad posmoderna se contenta con lo superficial, lo light. Al respecto, Mario Vargas Llosa señala:

La literatura light, como el cine light y el arte light, da la impresión cómoda al lector, y al espectador, de ser culto, revolucionario, moderno, y de estar a la vanguardia, con el minimo esfuerzo intelectual. De este modo, esa cultura que se pretende avanzada y rupturista, en verdad propaga el conformismo a través de sus manifestaciones peores: la complacencia y la autosatisfacción. ${ }^{17}$

Como preconiza la economía liberal: la producción se regula por la demanda, es claro que un mercado ávido de literatura y arte light producirá inmediatamente una oferta de literatura y arte light. Lo que hace que el ejercicio de pensar haya sido enviado al desván de las cosas pasadas, y cuando esto sucede:

cuando una cultura ha relegado al desván de las cosas pasadas de moda el ejercicio de pensar y sustituido las ideas por las imágenes, los productos literarios y artísticos pasan a ser promovidos, y aceptados o rechazados, por las técnicas publicitarias y los reflejos condicionados en un público que carece de defensas

17 Vargas, 15. 
intelectuales y sensibles para detectar los contrabandos y las extorsiones de que es victima. ${ }^{18}$

Es decir, las personas son menos analíticas y más propensas a ser llevadas de un lado al otro, en el inagotable mercado de las ideas.

Tristemente, "Hoy reina la primacía de las imágenes sobre las ideas. Por eso los medios audiovisuales, el cine, la televisión e internet han ido dejando rezagados a los libros". ${ }^{19}$

Es evidente que una sociedad fundada sobre el facilismo no puede tener futuro. Retornando a Ortega, tenemos que:

La división más radical que cabe hacer de la humanidad es esta, en dos clases de criaturas: las que se exigen mucho y acumulan sobre si mismas dificultades y deberes, y las que no se exigen nada especial, sino que para ellas vivir es ser en cada instante lo que ya son, sin esfuerzo de per-

18 Ibíd., 16.

19 Ibíd., 19 fección sobre sí mismas, boyas que van a la deriva. ${ }^{20}$

Hay grandes desafíos que enfrentamos como sociedad, y una mentalidad light no los resolverá, o como pregunta Vargas Llosa " $¿ E l$ puro entretenimiento es capaz de armar a una sociedad suficientemente como para enfrentar todas esas problemáticas?"21

\section{Un mundo orientalizado}

Uno de los aspectos más interesantes de la sociedad occidental, de inicios del siglo XXI, es el creciente interés que demuestran millones de personas por las filosofías y religiones orientales. Hace algunos años atrás, caminaba por las calles de la ciudad de Lima, cuando un anuncio llamó mi atención, era una invitación para participar de una conferencia sobre la filosofía platónica. La institución que organizaba esta conferencia se llamaba "Nueva Acrópolis". Decidí entrar y escuchar la conferencia. Fue decepcionante escu-

20 Ortega, 57.

21 Vargas, 19. 
char una exposición de las ideas de Platón respecto de la muerte y la inmortalidad del alma sin un atisbo de crítica, como si los escritos de Platón fuesen verdades reveladas. Se presentaban las principales ideas de la reencarnación camufladas de filosofía. Definitivamente no era una conferencia filosófica, por el contrario, tenía las características de un discurso religioso.

Una de las características de la sociedad posmoderna es la difusión que se tiene de las reli100 giones y el pensamiento propios de las culturas orientales: la reencarnación, el panteísmo y la meditación trascendental. En suma, se trata de un espiritualismo exento de la creencia en un Dios personal y trascendente. Paradójicamente, la sociedad del mayor avance tecnológico en la historia de la humanidad se ve seducida por el influjo de la espiritualidad oriental, un tipo de espiritualidad que promete al individuo alcanzar el máximo de su potencial, sin la ayuda de la razón o del Dios de la Biblia.
De esta manera, el vacío espiritual que ha dejado la proclamación nietzscheana de "la muerte de Dios" en el alma occidental, es llenado por los movimientos espirituales de inspiración oriental que atraen a millones de seguidores, gran parte de ellos hartos del cristianismo tradicional, un cristianismo que mayoritariamente ha perdido su poder vital, por haber caído en el abismo del mercantilismo televisivo o por haber sido atrapado en las ciénagas de la teología liberal.

\section{Un mundo con una reli- giosidad superficial}

Otro rasgo distintivo de la sociedad posmoderna es la proliferación de un cierto tipo de práctica religiosa totalmente superficial. Una fe sin compromiso y que no exige cambios radicales en el estilo de vida. Siendo que el posmodernismo exalta el papel de las emociones, los sentimientos y la imaginación, hay una creciente demanda por este tipo de experiencias emocionales, aun en el contexto religioso. En ese sentido, el ser humano ha pasa- 
do por alto la demanda bíblica del "creer para ver", y se ha sometido a la exigencia posmoderna del "sentir para creer", reemplazando así al viejo imperativo de la modernidad, "ver para creer".

Así como el espiritualismo oriental carece de exigencias en términos de cambios en los patrones de comportamiento y en la manera de situarse frente al mundo, este tipo de religiosidad superficial, presente en gran parte del cristianismo, se satisface con las experiencias extáticas que frecuentemente se dan en un clima de anarquismo litúrgico. El bullicio y el aleonamiento de la multitud han reemplazado a la serena y persuasiva exposición de la Palabra de Dios, la alabanza y el loor propios de la congregación de los santos han cedido su lugar al griterío babilónico y la búsqueda por la solidez doctrinal se ha convertido en la repetición monocorde de un recetario de autoayuda humanista.

En ese contexto de emocionalismo puro, no hay lugar para un crecimiento verdadero de la experiencia cristiana, porque el crecimiento es el resultado de conectar, en profundidad, las raíces del espíritu a una viva relación con la divinidad, y eso demanda esfuerzo y perseverancia, en tanto que el emocionalismo solo se conforma con la superficialidad de la experiencia religiosa. En relación con este fenómeno, Rodas afirma: "Esta clase de iglesia preferiría mensajes animadores y anhelaría gozar del entretenimiento profesional en sus cultos, en vez de profundizar seriamente en todo el consejo de Dios. Lo que importa es "amar a Jesús" y disfrutar de sus múltiples bendiciones (materiales, emocionales y espirituales); no hay que "complicarse la vida" con estudios pesados. Es decir, a los fracasos del pasado, resultados de la ignorancia, pero de buen corazón, se suma hoy la superficialidad de una ignorancia declarada y celebrada". En conclusión, este tipo de religiosidad lleva a un cristianismo superficial que solo engendra cristianos superficiales.

Tristemente, este tipo de cristianismo superficial, y carente 
de compromiso, también ha llegado a la Iglesia Adventista del Séptimo Día. Fernando Canale sostiene, en base a sus observaciones personales durante los últimos cuarenta años, que "un creciente número de adventistas están adoptando estilos de vida mundanos".22 Entre las causas de esta secularización de estilo de vida cristiano Canale menciona: ${ }^{23}$ "(1) la secularización de la cultura occidental, (2) la crisis intelectual del pensamiento adventista, (3) el esquema de pensamiento práctico del liderazgo adventista, (4) la protestantización de la teología y práctica adventista y, (5) la doctrina evangélica de la justificación por la fe". ${ }^{24}$

22 Fernando Canale, “¿Por qué los adventistas están adoptando los estilos de vida seculares?", Theologika 26, No. 1 (2011): 89.

\section{Ibíd.}

24 Según Canale, Martín Lutero desconecta la salvación del estilo de vida,y, como resultado, el cristiano no incluye su estilo de vida como un componente vital de su experiencia de salvación en Cristo, lo que lo lleva a estar inerme frente a las tendencias secularizantes que el cristianismo moderno enfrenta. Fernando Canale, “PPor qué los adventistas están adoptando los estilos de vida seculares?", Theologika

\section{Los cristianos frente a la sociedad posmoderna}

¿Cuál es rol que les toca jugar a los cristianos en esta sociedad? ¿Qué pueden aportar los cristianos en favor de una sociedad que se derrumba sobre los frágiles cimientos del relativismo moral? Algunos podrían pensar que lo mejor sería apartarnos definitivamente del mundo y mantener una actitud distante e indiferente frente al destino de la sociedad. Frente a esta idea, se levantan las palabras de Cristo a sus seguidores: "Vosotros sois la sal de la tierra; pero si la sal se desvaneciere, ¿con qué será salada? No sirve más para nada, sino para ser echada fuera y hollada por los hombres" (Mt. 5:13).

Así como es necesaria la sal para evitar la putrefacción de la carne o el pescado, en una sociedad que se descompone día a día, son necesarias las fuerzas que obstaculicen la putrefacción. Es claro, que existen ciertas fuerzas que permitan una protección sobre el tejido social, tales como

26, N. ${ }^{\circ} 1$ (2011): 89. 
el estado (con su poder para formular y hacer cumplir las leyes) y el hogar (que incluye el matrimonio y la vida familiar). John Stott declaró: "Dios pretende que el más poderoso dentro de todos los restrictores dentro de la sociedad pecadora, lo constituya su propio pueblo redimido, regenerado y justo". ${ }^{25}$ Sin embargo, y siguiendo el ejemplo de la sal, esta solo es efectiva si mantiene su facultad de salar; del mismo modo, el cristiano solo puede ser ese agente restrictor de la putrefacción social en la medida que sea un verdadero cristiano y que viva a la altura de las exigencias de su profesión de fe, es decir, el cristiano, para ser efectivo, debe retener su semejanza a Cristo, de la misma manera que la sal debe conservar intacta su capacidad de salar. En palabras de Stott: "Si los cristianos se ajustan social y culturalmente a los no cristianos, y se contaminan con las impurezas del mundo, pierden su influencia. La influencia de los

25 John Stott, Contracultura cristiana: El mensaje del Sermón del Monte (Illinois, Estados Unidos: Ediciones Certeza, 1991), 66. cristianos en y sobre la sociedad depende de que sean distintos, no idénticos". 26

Cuando un cristiano vive los principios éticos de la Biblia, se coloca inevitablemente en contra de la ética posmoderna basada en el relativismo moral. $\mathrm{No}$ es que el cristiano busque esa confrontación, sino que esta es el resultado natural de los paradigmas opuestos con que se construyen la posmodernidad y la cristiandad.

Elena de White dice: "Los discípulos de Cristo han de volverse semejantes a Él, es decir, adquirir por la gracia de Dios un carácter conforme a los principios de su santa ley. Esto es lo que la Biblia llama santificación”. ${ }^{27}$ En ese sentido, la mayor contribución que el cristianismo puede hacer a la sociedad, es presentarle un camino alternativo al del posmodernismo relativista. Toca a los cristianos ser la luz de un mundo sumido en la os-

26 Stott, 67.

27 Elena de White, El conflicto de los siglos (Mountain View, California: $\mathrm{Pu}-$ blicaciones Interamericanas, 1954), 523. 
curidad moral y espiritual. Jesús dijo que esa luz son "las buenas obras", parece ser que las "buenas obras" es "una expresión general que abarca todo lo que un cristiano dice y hace porque es cristiano, cualquier manifestación externa y visible de su fe cristiana”. 28

El cristiano verdadero es un embajador de una sociedad superior, se conduce en esta sociedad terrena viviendo los valores de su ciudadanía celestial y, al hacerlo, se convierte en una luz de esperanza de un mundo mejor, por eso Jesús afirmó "vosotros sois la luz del mundo" (Mt 5:14).

Pero la luz del cristiano no es una luz propia, es una luz que procede de una fuente superior, así como la luna refleja la luz del sol, el verdadero cristiano refleja la luz de Jesús que también afirmó: "Yo soy la luz del mundo" (Juan 8:12).

Ahora bien, la misión del cristiano no es solo iluminar, también es llevar a otras personas a colocarse en tal sintonía con Cristo, que puedan reflejar su inmarcesible luz. Es de esta manera que se debería propagar una auténtica revolución en la sociedad: la revolución del amor, del perdón y de la verdad. La verdadera esencia del mensaje cristiano es mostrar que el establecimiento del reino de Dios comienza por un verdadero cambio en el corazón del individuo.

\footnotetext{
28 Stott, 67.
} 